\title{
System-Functional Model of Personality Traits
}

\author{
Alexandr I. Krupnov, Dr., \\ Irina A. Novikova, PhD, \\ Yulia V. Kozhukhova \\ Peoples' Friendship University of Russia \\ 6 Miklukho-Maklaya St., Moscow, Russia, 117198
}

\section{Doi:10.5901/ajis.2013.v2n9p407}

\begin{abstract}
The article presents the theoretical basis and the essence of the System-Functional Model of the Personality Traits. This Model is based on the major theoretical propositions and constructs formulated in Russian psychology. The System-Functional Model of the organization of the personality traits, including two subsystems (motivational-semantic and regulatory-dynamic), eight components and sixteen variables which has been realized in the complex researches of sociability, persistence, inquisitiveness, self-organization (orderliness), responsibility, initiative, diligence, confidence, aggressiveness in various age, gender, professional, ethnic groups is described in detail.The system-functional model of the organization of the personality traits has been realized in the complex studies of sociability, persistence, inquisitiveness, self-organization (orderliness), responsibility, initiative, diligence, confidence, aggressiveness in various age, gender, professional, ethnic groups. This model has been applied by the Russian scientists in more than fifty Ph.D. theses. The program of systematic studying of the personality traits is considered. The special attention is given to the comparative research of personality traits within the framework of the system-functional approach that gives the possibility to conduct the most complex investigation of the individual distinctions between the people, which meets the requirements of the education, vocational guidance, psychological consultation and correction. The examples of concrete comparative empirical research are submitted and their basic results are analyzed.
\end{abstract}

Keywords: System-Functional Model, system-functional approach, personality traits, comparative research, system diagnostics, psychology of personality and individuality.

\section{Introduction}

The integral, system-functional approach to studying the personality and individuality (Krupnov, 2006-2009) is based on the major theoretical propositions formulated in Russian psychology: about the continuity of the dynamic, semantic and productive aspects of mental activity (Brushlinsky, 1978; Nebylitsyn, 1976; Rubenstein, 1973, etc.), about the unity of the personal and individual formations of the subject (Ananyev, 1980; Lomov, 1984; Merlin, 1996, etc.), about the system nature of the attitudes of the personality (Ananyev, 1980; Abulkhanova-Slavskaya, 1991; Bodalev, 1988; Myasischev, 1960; etc.).

In due time B.G. Ananyev pointed out, that separate properties of the personality and the character traits include not only certain subject attitudes, but also the ways of their realization, motives, emotional, intellectual and productive characteristics (Ananyev, 1980). Specifying on the system nature of the properties of the personality and character traits, S.L. Rubinstein remarked, that they represent an alloy of views, feelings, promptings of the acting subject in unity and interpenetration with the objective course and the results of his activity (Rubinstein, 1973). A.A. Bodalev emphasizes, that the property of the personality acts as a specific integration of more individual attitudes to the various events of the surrounding environment and inherently represents the unity of knowledge, experience and behaviour (Bodalev, 1988).

As one of the all-personality continuums describing the integral features of human behaviour, V.D. Nebylitsyn singled out the general mental activity of the individual which in this or that kind is contained in various personal formations: temperament, character, abilities: "The concept of the general activity unites the group of the personal qualities causing the internal need, the tendency of the individual for the effective development of the external environment, for self-actualization concerning the external world. Such a need can be realized either in an intellectual, or in kinetic (including speech developing), or in the social (communication) aspect, and according to it several kinds of general activity can be singled out" (Nebylitsyn, 1976, p. 251). "The degrees of activities are distributed from 
sluggishness, inertness and passive contemplation on the one hand up to the maximum degrees of energy, powerful swiftness of actions and constant rise - on the other hand. Thus the direction, quality and the level of realization of these tendencies are defined by the other ("substantial") properties of the personality - its intellectual and characterological properties, the whole complex of its attitudes and motives" (Nebylitsyn, 1976; p. 178).

Relying on the ideas stated by V.D. Nebylitsyn, A.I. Krupnov suggested the model of the integrally-functional analysis of the activity of a person (Krupnov, 1983, 1984). Thus in the structure of the integral activity three interconnected components: motivational-semantic, operational-dynamic and productive-resulting are allocated. "Hence, the complete analysis of the personality's activity should include: firstly, the characteristic of motivation, interests, orientation, etc., i.e. its substantial, functional-semantic part; secondly, the formal-dynamic aspect, i.e. the characteristic of the process of interaction, its volume, intensity, etc.; thirdly, the characteristic of the result of the activity and interaction as a whole" (Krupnov, 1983; p. 15). In this structure the essence of the activity as the process, "providing the continuous interaction with the world" (Krupnov, 1984) is precisely shown. Later on, proceeding from such an understanding of the structure of activity, the system-functional model of the analysis of the properties of personality considered as the characteristics of the all-personality activity in various spheres, was devised by A.I. Krupnov.

Originally the structure of the personality properties included the four basic components. Then the structure of the components was supplemented, and the structure was transformed into a six-component model of the structure of personality properties. It was supposed, that each property represented an alloy of the individual and personal characteristics functionally interconnected. The motivational, cognitive and productive components were considered as the personal characteristics. The so-called individual attributes, to the greater degree determined the operationallydynamic, emotionally-expressive and regulatory components. Each component contained the two variables, as an additional variable, the difficulties preventing the realization of a certain personal property were considered. In 1999 the suggested model was supplemented by two more components, and acquired its final form.

\section{Methodology}

According to the eight-component model of the analysis, the personality trait is studied as a complete and systematic formation. The two blocks are singled out in its structure: the motivational-meaningful, including the attitudinal-target, motivational, cognitive and productive components in its structure, and the regulatory-dynamic, containing the emotional, dynamic, regulatory, reflective-evaluative components of the personality trait. Each component contains two variables (table 1).

Table 1. The System-Functional Model of organization of the personality traits by A.I. Krupnov

\begin{tabular}{|c|c|c|}
\hline Blocks & Components & $\begin{array}{c}\text { Variables } \\
\end{array}$ \\
\hline \multirow{8}{*}{ The motivational-meaningful } & \multirow{2}{*}{ Attitudinal-target } & Socially Significant Purposes \\
\hline & & $\begin{array}{l}\text { Personally Significant Purposes } \\
\end{array}$ \\
\hline & \multirow{2}{*}{ Motivational } & Sociocentric Motivation \\
\hline & & Egocentric Motivation \\
\hline & \multirow{2}{*}{ Cognitive } & Profound Awareness \\
\hline & & Superficial Awareness \\
\hline & \multirow{2}{*}{ Productive } & Objectness \\
\hline & & Subjectness \\
\hline \multirow{8}{*}{ The regulatory-dynamic } & \multirow{2}{*}{ Dynamic } & Energy (Ergicity) \\
\hline & & Inactivity (Aergicity) \\
\hline & \multirow{2}{*}{ Emotional } & Sthenic Emotions (sthenicity) \\
\hline & & Asthenic Emotions (asthenicity) \\
\hline & \multirow{2}{*}{ Regulatory } & Internal Regulation (internality) \\
\hline & & External Regulation (externality) \\
\hline & \multirow{2}{*}{ Reflective-evaluative } & Operational Difficulties \\
\hline & & Personal Difficulties \\
\hline
\end{tabular}

First of all, the substantial-semantic subsystem provides the selection and priority of the certain incentives (sociocentric or egocentric), the depth and accuracy of the semantic values (profound or superficial awareness), the sphere of the character traits application in the subject kinds of activity (objectness) or in self-expression, self-development of the 
subject (subjectness). Thus the leading strategy of functioning of the given subsystem is the subject's choice of the dominating meanings, orientations and promptings by the principle "both this and that, but something to a greater degree".

The regulatory-dynamic subsystem represents the unity of the dynamic, emotional and regulatory variables. Thus the majority of them consist of bipolar, internally opposite attributes; therefore, the variables of the regulatory-dynamic subsystem are conventionally divided into "harmonious" and "non-harmonious". The basic function of this subsystem, first of all, is connected with the maintenance of regulatory-energetic basis of personality traits.

At the same time between the specified subsystems of personality traits, there exist specific relations depending on its actual/certain traits. This fact gives the grounds to assert that the indissoluble unity of these subsystems defines the specific structure and the nature of the various personality traits which ensure both the active and the adaptive functions in the communication and the activity of the subject.

Let's consider the components and variables of the system-functional model in more detail.

Assessing the variable socially significant purposes of the attitudinal-target component we should take into account the specific goals, attitudes, intentions and interests of public character, at which the investigated personality traits are aimed, and when assessing the variable personally significant purposes the attitudes, intentions and interests of personal character should be considered.

The motivational component includes the variables sociocentricity (incentive connected with the sense of duty, the aspiration to realize the intentions of other people, to help them, to deserve respect, to master a trade better, etc.) and egocentricity (incentive caused by the desire to realize the opportunities and abilities, the aspiration to be independent, to improve one's material welfare, etc.).

The cognitive component contains the variables of profound awareness (the subject's deep and profound ideas about the personality trait, awareness, the knowledge of its basic essential attributes, etc.) and superficial awareness (the subject possessing the general information on the certain functions of the given trait, its manifestations in activity which can have a nonspecific character and be inherent).

The variable of objectness of the productive component characterizes the results achieved by the person with the help of a certain personality trait in studying, work, relations with other people, and subjectness characterizes the results of solving personal problems, self-education, creating well-being, etc.

The variable of ergicity (energy) of the dynamic component reflects a variety of methods and ways of the realization of the personality traits: the force, stability and constancy of the aspirations for the realization of the certain attitudes to the reality, and the variable of inergy (inertia, inactivity) reflects the absence or weak manifestation of the given attributes.

The emotional component includes the variables: sthenicity (domination of the emotions of pleasure, pride, optimism, an anticipation of a positive outcome of intentions, etc.) and asthenicity (domination of anxiety, pessimism, fear, apathy, etc. connected with the manifestation of a certain character trait).

The regulatory component is characterized by the activity (internality) or passivity (externality) of the self-regulation of personality traits. The expressiveness of the internality variable testifies to the person's conviction, that all the success or failure in business depends only on him, his aspirations to achieve everything by himself and not to rely on circumstances or other people (an internal locus of control). The prevalence of the externality variable tells about the person's trust to chance, destiny, luck; his disbelief in his own powers and abilities (an external locus of control).

The reflective-evaluative component includes the variable of operational difficulties (informedness of the intellectual, communicative or conative habits and skills, etc.) and personal difficulties (a low self-esteem, anxiety, lack of self-confidence, etc.).

On the basis of the system-functional model A. Kurpnov developed personality inventories for the diagnosis and measurement of personality traits (Krupnov, 2008).

\section{Applied research based on the System-Functional Model}

Within the framework of the given model the psychological peculiarities of the following personality traits have been investigated: sociability, persistence, inquisitiveness, responsibility, initiative, orderliness, confidence, diligence, aggressiveness. Relying upon the system-functional model the individual characteristics of the speech activity and success in foreign language acquisition are investigated (Kozhukhova, 2010; Krupnov, \& Kozhukhova, 2012 etc.).

There has been offered and is realized the program of the systematic studying of each of the above mentioned personality traits, including the following directions of the research (Krupnov, 2007):

- the psychological structure of the property; 
- the peculiarities of its formation and development;

- the connections with genetic, psycho-physiological and environmental preconditions;

- gender, age, professional, ethno-psychological, psycho-pathological features;

- individually-typical and typological features;

- opportunities of correction and self-regulation.

The separate direction of research which has actively developed in the recent years is the research, in which several personality traits are considered in the comparative aspect. In our opinion such complex research allows to investigate the individual distinctions between the people more fully, which meets the requirements of the education, vocational guidance, psychological consultation and correction, therefore we shall dwell on the characteristics of this group of research in detail (Krupnov, 2009; Novikova, 2003; 2006; Yershova et al, 2012).

The comparative research conducted within the framework of the system-functional approach, may be conventionally divided into three groups: 1) the comparison of several personality traits between themselves, each of which is considered according to the system-functional concept; 2) the comparison of one trait examined within the framework of the system-functional concept, with the certain personality traits, analyzed and diagnosed with the help of other methodological approaches (for example, self-actualization, character accentuation, trust to people, etc.); 3) the comparison of several personality traits within the framework of the system-functional approach both between themselves, and with other personality traits or its manifestations in activity.

The main purpose of the research attributed by us to the first group, is revealing the similarity and specificity in the realization of the various personality properties examined within the framework of the system-functional approach (as a rule, the quantity, correlation, factorial indicators, and also, in some cases, the cluster structures are analyzed).

Within the framework of the eight-component model N.V. Kargina has carried out a comparative research of inquisitiveness, persistence and sociability in students (Kargina, 2005) with the purpose of revealing the common and specific in the psychological structures of the personality traits, representing the different spheres of the subject's relations - cognitive, conative and communicative. The comparative analysis of the quantitative characteristics showed, that, as a whole, average indices of the three analyzed traits are very close between themselves. It is only possible to note the prevalence (in comparison with the two other features) the ergicity, sthenicity and, especially, asthenicity of persistence; the prevalence of the personally significant purposes and internality of inquisitiveness; smaller expressiveness of the egocentricity of sociability. These distinctions are, most likely, connected with the psychological nature of the given qualities. The realization of persistence as a conative quality, probably causes the emotional reactions most strongly (especially in case of failure conceived); sociability as a communicative quality, is equally determined by the sociocentric and egocentric motives; and the inquisitiveness according to the students' conceptions, has internal regulation and personally significant purposes to the greatest degree.

In the correlation structures of inquisitiveness, persistence and sociability there has also been revealed the prevalence of similarity that is proved to be true by the results of the factorial analysis. In the factorial structures of the analyzed traits there were revealed two similar factors ("the factor of success" and "the factor of difficulties and problems") and one specific factor (the factor of "activity" for inquisitiveness, of "self-regulation" for persistence and "instability" for sociability).

Eventually, D.A. Shlyakhta investigated the problem of the ratio of the individually-typical traits of sociability, persistence, inquisitiveness, which were examined as the manifestations of activity of the personality in the different spheres of living activity - communicative, conative, cognitive (Shlyakhta, 2009, etc.). The conducted analysis has allowed to single out for each of the investigated personality traits, the four main types of their realization, the stability of whose basic characteristics is proved both on the different samples of examinees, and in the different spheres of the subject's relations:

- $\quad$ for the representatives of the instrumentally-semantic type ("active") the maximal parameters of the majority of the motivationally-semantic and instrumentally-harmonious variables, the minimal parameters of the main instrumentally-nonharmonious variables and difficulties are characteristic;

- $\quad$ for the representatives of the motivated-nonharminious type ("non-harmoniously active") the high parameters of the basic motivationally-semantic variables, the maximal or close to the maximal parameters of the main instrumentally-nonharmonious variables and difficulties are characteristic;

- for the representatives of the poorly-motivated type ("passive") - minimal or close to minimal the parameters of the majority of motivational-semantic and instrumental-harmonious variables, high parameters of difficulties are characteristic; 
- $\quad$ for the representatives of the selective type ("selectively active") - average indices of the basic motivationallysemantic and instrumentally-harmonious variables (at their domination over the instrumentallynonharmonious), very low parameters of difficulties are characteristic.

In the research which has been carried out by T.V. Nechepurenko (Novikova, Nechepurenko, 2007) there has been made a comparison of such features as sociability and aggression which belong to the communicative sphere, but at the same time they are opposed by their orientation.

The comparative analysis of the average indices of the variables of sociability and aggression has shown that they differ from each other significantly: the variables of the motivational, cognitive, productive components, and also the variable of internality of the regulatory component have more manifestation in sociability. The variable of externality and also the operational and personal difficulties are more expressed with aggression. These distinctions are most likely, connected to the socially-psychological nature of the studied character traits. Sociability as a socially approved trait, naturally, is more perceived and volitional. The manifestation and development of sociability in connection with the social reinforcement is more motivated. The big expectations of compensations in various spheres of the vital activities of the personality are connected with the demonstration of sociability, and the skillful use of this quality is closely connected to the "success" of the personality. The aggression in the social plan is more often estimated disapprovingly. Therefore its displays are more involuntary and are more often connected with different sort of difficulties and "failures".

As a result of the factorial analysis for each feature the two-factorial structure has been received. The first factor of sociability includes a complex of motivationally-semantic and instrumentally-harmonious variables ("the factor of success") which has also been described by other researchers. The second factor included asthenia, operational and personal difficulties with the negative significant weights; with positive significant weight - ergicity ("the factor of problems"). The first factor in the structure of aggression which has the main weight was singled out as the factor of "problems". In the case of aggression the difficulty is connected not with the lack of energy, but with the inability to restrain from reacting affect, therefore this factor can also be named "the factor of emotional-reaction aggression". The problems are caused not by the inability to find powers for maintaining contacts, but the inability to constrain the affective impulses, the uncontrollable propensity to react outwardly. The second factor of aggression includes sociocentricity and concreteness with positive significant weights and the egocentricity and subjectness ("the factor of instrumental aggression").

Thus, there was vividly shown the specificity of the factorial structures of sociability and aggression, consisting in the opposing orientation of these traits, which is reflected in the distribution of the factorial loadings: the more loaded factor of sociability is the factor of "success", and the most loaded factor of aggression is the factor of "problems". Besides, the specificity of the psychological structures of the analyzed traits is manifested in the structures of the difficulty factors to a higher degree. The presence of difficulties in the communication is characterized by the lowered tone, and the problems related to aggression, are connected, first of all, with the propensity for the affective reaction in view of an excessive sensitivity to the real or to the alleged threats and insults.

To the second group of the complex research there belong the works on revealing the ratio of sociability with trust to people (Zhuravlyova, 2004), accentuations of the character (Kovalenko, 2007), attitudes towards the interpersonal interaction (Solonkina, 1996); initiative with creativity (Zharikova, 2011), self-actualization (Polskaya, 2005); inquisitiveness with creativity (Tskhay, 2000); diligence with the features of child-parental relations in high school students (Kameneva, 2005), etc.

One of the latest works conducted in the given aspect, is the research of the ratio of self-confidence of the employees of the commercial organizations with the level of their self-actualization, and also the parameters of the efficiency of the professional work (Zamalatdinova, 2011). The peculiarities of the ratio between the parameters of confidence and self-actualization of the employees of the commercial organizations which are most vividly shown in close communication with the instrumentally-style variables of confidence, with the basic scales of self-actualization have been established: the employees with the least amount of problems in the realization of confidence have as a whole a higher level of self-actualization. It is also shown, that the confidence and self-actualization are connected with the efficiency of the professional work of the employees of the commercial organizations, thus the most professional employees, as a rule, possess a higher level of self-actualization and practically do not have any problems and negative experiences in the realization of confidence. Besides the types of the realization of personal confidence of the commercial organizations employees, which are similar to the types described above on the key parameters, persistence, inquisitiveness have also been revealed in the research. A thorough analysis has shown that the maximum level of self-actualization and efficiency of the professional work is observed in the representatives of the selective and instrumentally-semantic types, and the minimal, in the representatives of the motivational-non-harmonic type. 
The research we included in the third group, are the most complex as they unite the lines of the comparative analysis described by us in the first two groups.

In one of the first works of the above-mentioned trend on the basis of the six-component model, the research of the psychological manifestations of the individually-typical features of sociability, persistence and inquisitiveness in the texts as products of individual speech activity (Fomina, 2002) has been carried out.

With the use of the eight-component model there have been conducted the comparisons of persistence and initiative with the career orientations and the specificity of the educational activity of students (Polyanskaya, 2008); of sociability, aggression with the aggressive forms of behaviour in the cadets of military higher school (Isayeva, 2008); of sociability and confidence with the features of the socially-psychological adaptation of students in higher school (Akimova, 2010), etc.

In the given works the similarity in the factorial structures of the analyzed traits is confirmed. For the majority of the investigated qualities (sociability, persistence, inquisitiveness, initiative) "the factor of success" and "the factor of problems (difficulties)" are steadily singled out. The existence of the similar individually-typical variants of the realization of the various personal features (with the little variations in structures and in names) also proves to be true: instrumentally-semantic, selective, instrumentally-non-harmonic, external. It is convincingly shown, that the most perspective and practically significant direction of the complex researches within the framework of the system-functional approach is not only the comparison of the personality traits between themselves, but also with the other characteristics of the person and activity: the features of educational activity, the sociometrical status, career orientations, the efficiency of professional work, etc.

\section{Conclusions}

Thus, the potential and efficiency of the system-functional approach is connected to the fact that, firstly, it promotes solving the fundamental problem of overcoming the gap between the dynamic, semantic, productive and other characteristics while studying various mental formations and the other characteristics which are complete and systematic by their nature. Secondly, it gives an opportunity of studying the structure of personal features and internal mechanisms of the interaction of their various components. Thirdly, it creates the preconditions for the development of the scientifically proved technologies of developing and correcting various personal properties.

The model of the system-functional structure of the personality properties has become the basis of more than 50 dissertational researches and is used in higher schools and research institutes of different cities of Russia and abroad (Moscow, St Petersburg, Minsk, Yekaterinburg, Ryazan, Bryansk, Biysk, Togliatti, Tambov, Magnitogorsk, etc.). On the social and differential psychology department of the Peoples' Friendship University of Russia there is organized a scientific school based upon the system-functional analysis of personality properties and their displays in various kinds of activities, scientific researches, and the projects of the school were repeatedly supported by the Russian Foundation for the Humanities.

\section{References}

Abulkhanova-Slavskaya K.A. (1991). Strategiya zhizni [Life strategy]. Moscow: Misl' (in Russian).

Akimova A.R. (2010). Osobennosti uverennosti i obschitelnosti studentov na raznikh etapakh sotsialno-psikhologicheskoj adaptatsii v vuze [Peculiarities of confidence and sociability of students on different stages of social psychological adaptation to higher school]. Ph.D. Thesis. Moscow: PFUR (in Russian).

Ananyev B.G. (1980). Izbrannye psikhologicheskie trudi [Selected psychological works]. Moscow: Pedagogika (in Russian).

Bodalev A.A. (1988). Psikhologiya lichnosti [Personality Psychology]. Moscow: MSU (in Russian).

Brushlinsky A.V. (1978). O vzaimosvyazi prirodnogo i sotsialnogo v psikhologicheskom razvitii cheloveka [The relationship between the natural and the social in human psychological development]. In Problems of human genetic psychophysiology. Moscow: Nauka (in Russian).

Fomina N.A. (2002). Svoystva lichnosti i osobennosti rechevoy deyatelnosti [Personality traits and characteristics of speech activity]. Ryazan: Uzorochye (in Russian).

Isayeva I.S. (2008). Individualno-tipologicheskie osobennosti obschitelnosti i agressivnosti kursantov voennogo vuza [Individual and typological features of sociability and aggressiveness of the military college students]. Ph.D. Thesis. Moscow: PFUR (in Russian).

Kargina N.V. (2005). Sravnitelnoe issledovanie luboznatelnosti, nastoychivosti i obschitelnosti studentov [Comparative research of inquisitiveness, persistence and sociability of students]. Ph.D. Thesis. Moscow: PFUR (in Russian).

Kovalenko E.A. (2007). Osobennosti obschitelnosti pri razlichnikh tipakh aktsentuatsii kharaktera [Peculiarities of sociability of person with different types of character accentuation]. Ph.D. Thesis. Moscow: PFUR (in Russian). 
Kozhukhova Yu.V. (2010). Quantitative and qualitative characteristics of persistence of students with different levels of progress in foreign language learning. Bulletin of Peoples' Friendship University of Russia. Series: Psychology and Pedagogics, 1, 78-82.

Krupnov A.I. (1983). Psikhophiziologicheskiy analiz individualnikh razlichiy aktivnosti lichnosti [Psychophysiological analysis of individual differences in the activity of personality]. Sverdlovsk: SGPI.

Krupnov A.I. (1984). Psikhologicheskie problemy issledovaniya aktivnosti cheloveka [Psychological problems of human activity research]. Voprosy Psikhologii, 3, 25-32 (in Russian).

Krupnov A.I. (2006). Sistemno-dispozitsionniy podkhod k izucheniyu lichnosti i yeyo svoystv [The system-dispositional approach to studying the personality and its properties]. Bulletin of the Peoples' Friendship University of Russia. Series: Psychology and Pedagogics, 1, 63-73 (in Russian).

Krupnov A.I. (2007). Systemnaya diagnostika i korrektsiya obschitelnosti [System diagnostics and correction of sociability]. Moscow: PFUR (in Russian).

Krupnov A.I. (2008). Psikhodiagnostika svoystv lichnosti i temperamenta [Psychodiagnostics of personality traits and temperament]. Moscow: MGUDT (in Russian).

Krupnov A.I. (Eds.) (2009). Kompleksnie isledovaniya svoystv lichnosti: Nauchnaya shkola A.I. Krupnova [Comprehensive study of personality traits: Scientific School of A.I. Krupnov]. Moscow: PFUR (in Russian).

Krupnov A.I., Kozhukhova Yu.V. (2012). Personality Traits and Success in Foreign Language Acquisition. Bulletin of Peoples' Friendship University of Russia. Series: Psychology and Pedagogics, 1, 107-111.

Lomov B.F. (1984). Metodologicheskie i teoreticheskie problemy psikhologii [Methodological and theoretical problems of psychology]. Moscow: Nauka (in Russian).

Merlin V.S. (1996). Psikhologiya individualnosti [Psychology of individuality]. Moscow-Voronezh (in Russian).

Myasischev V.B. (1966). Osnovnie problemy i sovremennoe sostoyanie psikhologii otnosheniy cheloveka [The main problems and the modern state of the psychology of human relationships]. In Psikhologicheskaya nauka $v$ SSSR. Moscow: APN RSFSR (in Russian).

Nebylitsyn V.D. (1976). Psikhophiziologicheskie issledovaniya individualnikh razlichij [Psychophysiological studies of individual differences]. Moscow: Nauka (in Russian).

Novikova I.A. (2003). K probleme kompleksnogo izucheniya individualnosti [To the problem of comprehensive study of individuality]. Bulletin of Peoples' Friendship University of Russia. Series: Psychology and Pedagogics, 1, 98-107 (in Russian).

Novikova I.A. (2006). K probleme sravnitelnogo issledovaniya chert kharaktera [To the problem of the comparative study of character traits]. Bulletin of Peoples' Friendship University of Russia. Series: Psychology and Pedagogics, 1, 83-92 (in Russian).

Novikova I.A., Nechepurenko T.V. (2007). Sravnitelniy analiz obschitelnosti i agressivnosti studentov [Comparative analysis of sociability and aggressiveness of students]. Bulletin of Peoples' Friendship University of Russia. Series: Psychology and Pedagogics, 1, 20-28 (in Russian).

Novikova I.A., Zamaldinova G.N. (2010). Lichnostnaya uverennost' i uroven' samoaktualizacii sotrudnikov kommercheskikh organizatsiy [Self-confidence of Personality and the level of Self-actualization of the Employees of Commercial Organizations]. Bulletin of Peoples' Friendship University of Russia. Series: Psychology and Pedagogics, 2, 21-26 (in Russian).

Polskaya A.Yu. (2005). Sootnoshenie iniciativnosti i samoaktualizacii lichnosti [Correlation between initiative and self-actualization of personality]. Ph.D. Thesis. Moscow: PFUR (in Russian).

Polyanskaya E.N. (2008). Individualno-tipicheskie osobennosti nastoychivosti, iniciativnosti i karernikh orientatsiy studentov [Individuallytypical peculiarities of persistence, initiative and career goals of students]. Ph.D. Thesis. Moscow: PFUR (in Russian).

Rubinshtejn S.L. (1973). Problemy obschey psikhologii [Problems of General Psychology]. Moscow: Pedagogika (in Russian).

Solonkina O.V. (1996). Svyaz' obschitelnosti s razlichnymi ustanovkami uchaschikhsya na mezhlichnostnoe vzaimodeistvie [Relationship between pupils' sociability and different attitudes to interpersonal interaction]. Ph.D. Thesis. Moscow: PFUR (in Russian).

Tskhay I.K. (2000). Lichnostnie i kognitivnie aspekty kreativnosti [Personality and cognitive aspects of creativity]. Ph.D. Thesis. Moscow: PFUR (in Russian).

Shlyakhta D.A. (2009). Individualno-tipicheskie osobennosti aktivnosti lichnosti v kommunikativnoj, volevoy i poznavatelnoy sferakh [Individually-typical characteristics of personal activity in communicative, conative and cognitive spheres]. Ph.D. Thesis. Moscow: PFUR (in Russian).

Yershova R.V., Zinkovskaya S.M., Krupnov A.I., Novikova I.A., Pryadein V.P. (2012). Kompleksnye issledovaniya lichnosti i individualnosti [Comprehensive study of personality and individuality]. Moscow: Argamak (in Russian).

Zamalatdinova G.N. (2011) Sootnoshenie individualno-tipicheskikh osobennostei uverennosti s urovnem samoaktualizacii sotrudnikov kommercheskikh organizacii [Correlation of individually-typical features of confidence with the level of self-actualization of the employees of commercial organizations]. Ph.D. Thesis. Moscow: PFUR (in Russian).

Zharikova A.S. (2011). Sootnoshenie initsiativnosti i kreativnosti lichnosti [Correlation of initiative and creativity of the personality]. Ph.D. Thesis. Moscow: PFUR (in Russian).

Zhuravleva L.A. (2004). Svyaz' obschitelnosti lichnosti i doveriya k lyudyam [Correlation between sociability and trust to people]. Ph.D. Thesis. Moscow: PFUR (in Russian). 